\title{
Adatok a Látrányi Puszta Természetvédelmi Terület medveállatka (Tardigrada) faunájához
}

\author{
VARGHA BÉLA
}

\begin{abstract}
Laboratory for Ecology, Department of Soil-Hygiene, National Institute of Environmental Health, H-1097 Budapest, Gyáli út 2-6., Hungary
\end{abstract}

Vargha B.: Data to the water-bear (Tardigrada) fauna of Látrányi Puszta Nature Conservation Area Abstract:: From the 65 moss and 8 lichen samples of the surveyed area 14 water-bear species have been reported. The samples are generally poor in species and one third of it did not contain water-bear at all. 3 species were new in the water-bear fauna of Somogy County.

Keywords: Tardigrada, faunistical survey, Hungary

\section{Bevezetés}

A Látrányi Puszta Természetvédelmi Területet a Környezetvédelmi és Területfejlesztési Minisztérium 8/1992(III.25.) KTM számú rendeletével létesítette. A védelem alá vont természeti terület 223,6 ha nagyságú, döntően gyep -és erdő művelési ágba tartozik.

Éghajlata mérsékelten meleg és mérsékelten nedves. Az évi középhőmérséklet $10,2{ }^{\circ} \mathrm{C}$, az évi csapadékmennyiség $650 \mathrm{~mm}$. Talaja főleg karbonátos homoktalaj.

A védett terület zoológiai feltárását az Egri Tanárképző Főiskola kezdeti kutatásait követően a Somogy Megyei Múzeum Természettudományi Osztálya szélesítette ki és mélyítette el.

Mivel a terület Tardigrada-faunájáról ezideig adatokat nem ismertünk, Dr. Ábrahám Levente témavezető megtisztelő felkérésére - Héra Zoltánnak a vizsgálati minták begyưjtésével segítő szívességével - 2001. évben vizsgálatokat végeztem a terület Tardigrada-faunájának megismerése céljából.

\section{Anyag és módszer}

2001. év folyamán 8 mintavételi területről összesen 73 - talajról, fatörzsről, kőről illetve mütárgyról származó - moha- és zuzmó-minta került begyűjtésre.

A 24 órás csapvizes áztatást követően ülepítéses-flotációs módszerrel (VARGHA 1997) történt a medveállatkák kivonása. A talált egyedek polivinil-laktofenolt tartalmazó tartós preparátumok formájában kerültek megőrzésre.

A megvizsgált 65 moha- és 8 zuzmó-minta $74 \%$-a talajról, $22 \%$-a kőről, illetve mütárgyról és $4 \%$-a fatörzsről származott. A mintavételi helyeket az 1. ábra (térkép), az egyes vizsgálati minták származási adatait az 1. táblázat tartalmazza. 


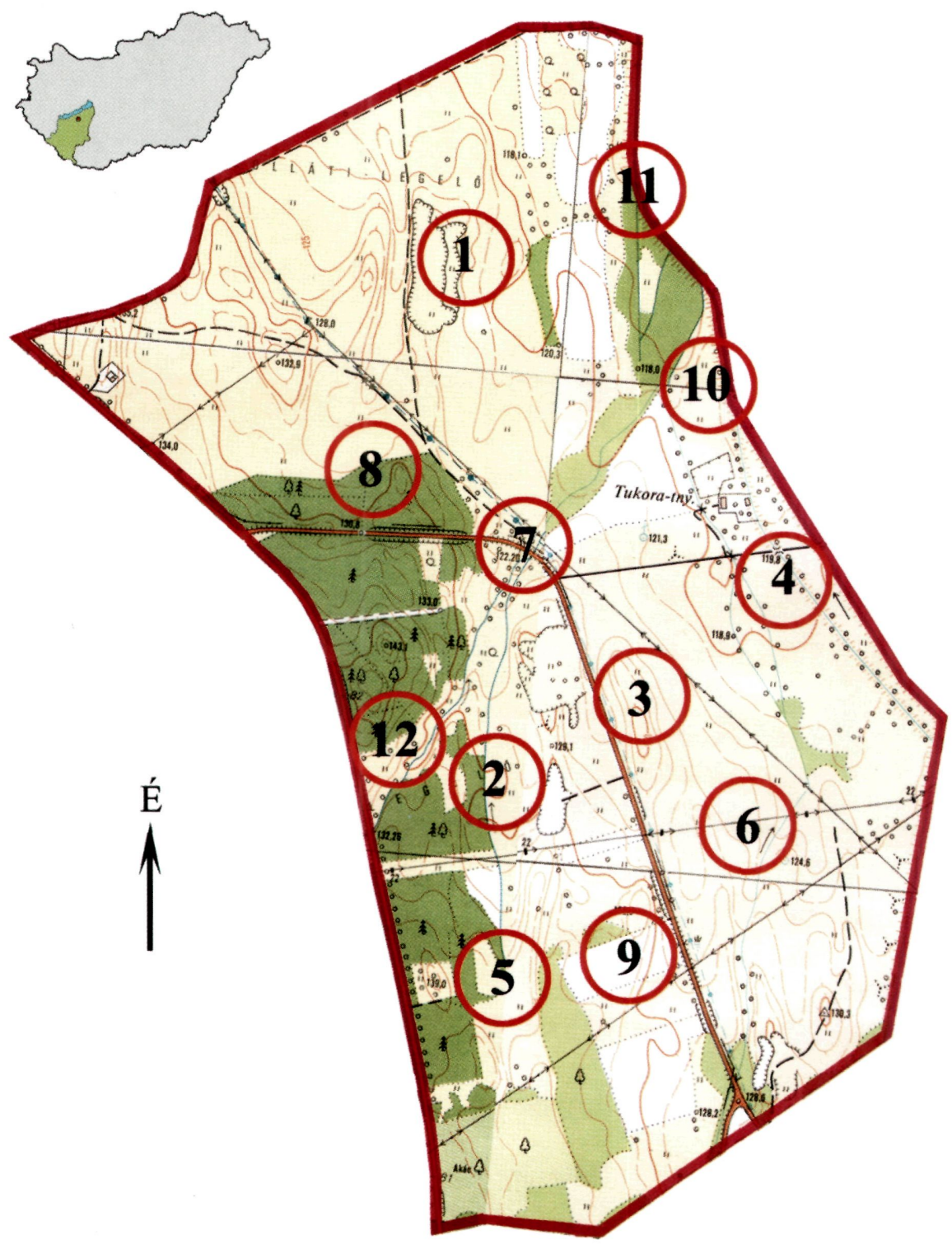

1. ábra: Tardigrada mintavételi helyek a Látrányi Puszta Természetvédelmi Területen 


\section{1. táblázat: A látrányi vizsgálati minták származása}

\begin{tabular}{|c|c|c|c|c|}
\hline Sorszám & Mintavételi terület & A vizsgálati minták és származásuk & $\begin{array}{c}\text { A pontminták } \\
\text { száma }\end{array}$ & \begin{tabular}{|c} 
A mintavétel \\
idōpontja
\end{tabular} \\
\hline 1. & 1. Kiszáradó mocsárrét & moha talajról & 5 & 2001.09 .06 \\
\hline 2. & 3. Homoki gyep & moha talajról & 5 & 2001.07 .03 \\
\hline 3. & 3. Homoki gyep & zuzmó talajról & 5 & 2001.07 .03 \\
\hline 4. & 4. Tetves- patak partja & moha partvédõ betont eknõrõl & 5 & 2001.05 .24 \\
\hline 5. & 4. Tetves- patak partja & moha vizügyi mưtárgyról & 4 & 2001.06 .24 \\
\hline 6. & 4. Tetves- patak partja & zuzmó vízügyi mûtárgyról & 1 & 2001.06 .24 \\
\hline 7. & 4. Tetves- patak partja & zuzmó vízïgyi mûtárgyról & 1 & 2001.06 .24 \\
\hline 8. & 4. Tetves- patak melletti fûzliget & moha fatörzsrõl & 1 & 2001.07 .03 \\
\hline 9. & 5. Éger-erdõ patakja mellett & moha talajról & 5 & 2001.05 .24 \\
\hline 10. & 5. Tölgyes erdófolt & moha talajról & 5 & 2001.07 .03 \\
\hline 11. & 5. Fenyves erdõtag & moha talajról & 5 & 2001.07 .03 \\
\hline 12. & 5. Fenyves erdōfolt tisztása & zuzmó talajról & 1 & 2001.09 .06 \\
\hline 13. & 6. Kiszáradó mocsár, páfrányos & moha talajról & 2 & 2001.05 .24 \\
\hline 14. & 6. Kiszáradó mocsár, sás tövei & moha talajrol & 3 & 2001.05 .24 \\
\hline 15. & 6. Mocsárrét, gémeskút & moha talajról & 5 & 2001.07 .03 \\
\hline 16. & 6. Száraz homoki gyep & moha talajról & 5 & 2001.05 .24 \\
\hline 17. & 8. Elegyes tölgyes & moha talajról & 3 & 2001.09 .06 \\
\hline 18. & 8. Elegyes tölgyes & moha fatörzsrõl & 2 & 2001.09 .06 \\
\hline 19. & 10. Tetves- patak partja & moha patak kövérõl & 1 & 2001.09 .06 \\
\hline 20. & 10. T etves- patak partja & moha vízvédmûrõl & 4 & 2001.09 .06 \\
\hline 21. & 11. Elegyes tölgyes & moha talajról & 5 & 2001.09 .06 \\
\hline \multicolumn{3}{|c|}{ Az összes pontminta száma } & 73 & \\
\hline
\end{tabular}

A vizsgálati mintákat gyüjtőtte: Héra Zoltán

\section{2. táblázat: Az egyes mintákban talált Tardigrada-fajok}

(A minta sorszáma az 1. táblázatban közölt Tardigrada-fajok minta- sorszámoknak felelnek meg).

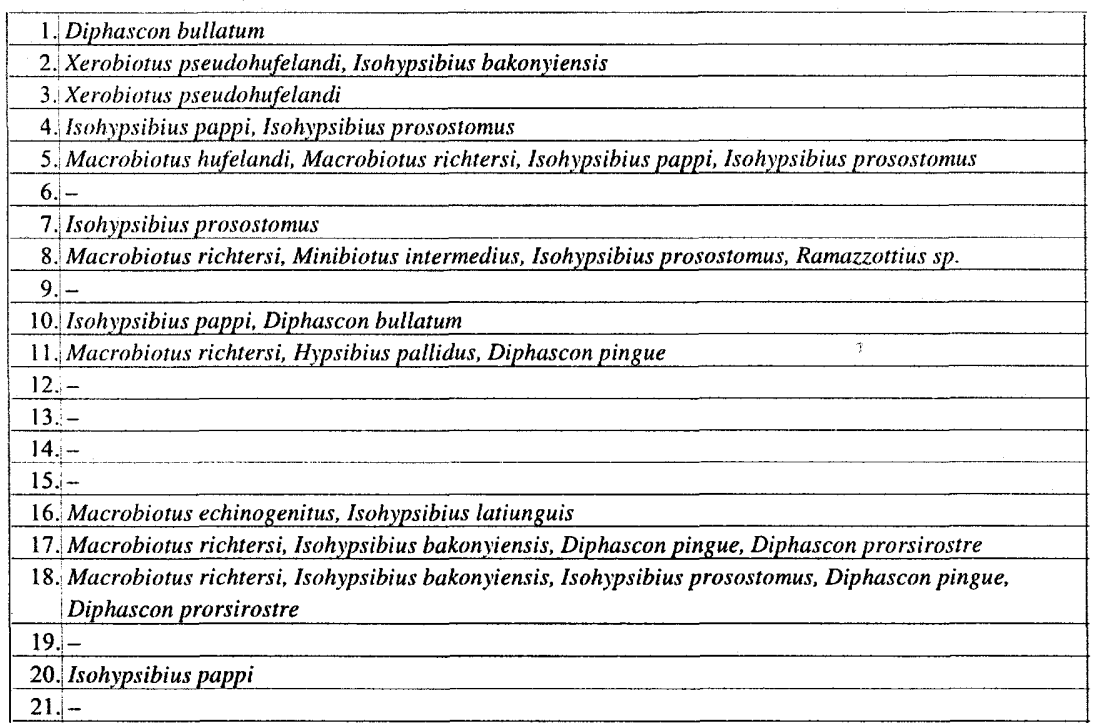




\section{Eredmények}

A vizsgálati mintákból 14 Tardigrada faj egyedeit sikerült kimutatni. (3. táblázat.) A 6, 9, 12-15, 19 és a 21 sorszámú minták Tardigradákat nem tartalmaztak. Az egyes Tardigrada-fajok az alábbi mintákban fordultak elő:

Macrobiotus echinogenitus

6. számú mintavételi hely, száraz homoki gyep, talajról származó mohában

Macrobiotus hufelandi

4. számú mintavételi hely, Tetves-patak partja, vízügyi mütárgyról gyüjtött mohában

Macrobiotus richtersi

4. számú mintavételi hely, Tetves-patak partja, vízügyi mủtárgyról gyüjtött mohában; 4 . számú mintavételi hely, Tetves-patak melletti füzliget, fatörzsröl származó mohában; 5. számú mintavételi hely, fenyves erdőtag, talajról gyüjtött mohában; 8. számú mintavételi hely, elegyes tölgyes, talajról származó mohában; 8 . számú mintavételi hely, elegyes tölgyes, fatörzsön ćló mohában

Xerobiotus pseudohufelandi

3. számú mintavételi hely, homoki gyep, talajról gyüjtött mohában; 3. számú mintavételi hely, homoki gyep, talajról származó zuzmóban

Minibiotus intermedius

4. számú mintavćteli hely, Tetves-patak melletti füzliget, fatörzsröl gyüjtött mohában

Hypsibius pallidus

5. számú mintavétcli hely, fenyves erdőtag, talajról származó mohában

Isohypsibius bakonyiensis

3. számú mintavétcli hcly, homoki gyep, talajról gyüjtött mohában; 8 . számú mintavételi hely, clegyes tölgyes, talajról gyüjtött mohában; 8. számú mintavételi hcly, elegyes tölgyes, fatörzsön növő mohában

Isohypsibius latiunguis

6. számú mintavétcli hely, száraz homoki gyep, talajról gyüjtött mohában
Isohypsibius pappi

4. számú mintavételi hely, Tetves-patak partja, partvédő betonteknőről gyüjtött mohában; 4. számú mintavételi hely, Tetves-patak partja, vízügyi mütárgyról származó mohában; 5. számú mintavételi hely, tölgyes erdőfolt, talajról gyüjtött mohában; 10. számú mintavételi hely, Tetves-patak partja, víz-védmüről származó mohában

Isohypsibius prosostomus

4. számú mintavételi hely, Tetves-patak partja, partvédő betonteknőről származó mohában, 4. számú mintavételi hely, Tetves-patak partja, vízügyi mütárgyról gyüjtött mohában; 4. számú mintavételi hely, Tetves-patak partja, vízügyi mütárgyról gyüjtött zuzmóban; 4. számú mintavételi hely, Tetves-patak melletti füzliget, fatörzsön növô mohában; 8 . számú mintavételi hely, elegyes tölgyes, fatörzsról gyüjtött mohában

Diphascon (D.) bullatum

1. számú mintavételi hely, kiszáradó mocsárrét, talajon növö mohában; 5. számú mintavételi hely, tölgyes erdőfolt, talajról gyüjtött mohában

Diphascon (D.) pingue

5. számú mintavétcli hely, fenyves crdötag, talajról származó mohában; 8 . számú mintavételi hcly, elegyes tölgyes, talajról gyüjtött mohában; 8. számú mintavételi hely, elegyes tölgyes, fatörzsön növő mohában

Diphascon (A.) prorsirostre

8. számú mintavételi hely, clegyes tölgyes, talajról gyüjtött mohában; 8 . számú mintavételi hcly, clcgyes tölgyes, fatörzsröl származó mohában

Ramazzottius sp.: (A pontos fajmeghatározás nem volt lehetséges, mivel az egyetlen talált példánynál hiányzott a garatfö.) 4. számú mintavételi hely, Tetves-patak melletti füzliget, fatörzsön növő mohában

A mohamintákból mind a 14 Tardigrada-faj, míg a zuzmómintákból mindössze 2 faj volt kimutatható.

A Tardigrada-fajok előfordulása szempontjából leggazdagabbnak a talajról gyüjtött mohaminták (10 faj) és a fatörzsröl származó mohaminták (7 faj) bizonyultak. Mindöszsze 4 faj egyedei voltak a kőről, mütárgyról származó mohamintákban és 1 - 1 faj a talajról és mütárgyról gyüjtött zuzmómintákban.

\section{Következtetések}

A jelentős mintaszámot tekintve (l. táblázat) a terület Tardigrada faunája nem tekinthető különösen gazdagnak. A 8 mintavételi terület 73 vizsgálati mintájából összesen 14 faj jelenlétét sikerült megállapítani (3. táblázat). A fajok egyedszáma is meglehetősen 
alacsony volt és a minták egyharmada negatívnak bizonyult. (Különösen a 6. mintavételi helyről származó minták között volt sok a negatív.)

A vizsgált minták általában fajszegények. A pozitív minták közel kétharmadában mindössze egy vagy két faj fordult elö.

A Tardigradára pozitív minták $62 \%$-ában egy vagy két faj, $8 \%$-ában három faj és 15 $15 \%$-ában négy, illetve öt faj egyedei voltak kimutathatók.

A talált Tardigrada fajok legtöbbje közönséges és gyakori, mindössze 2 faj (X. pseudohufelandi és I. latiunguis) tekinthetö ritkábbnak.

A kimondottan szárazságtürő fajok hiányoztak.

(Egy faj pontosan - fajra - nem határozható meg, mivel a talált egyetlen példánynál hiányzik a garatfö.)

A leggyakoribb faj a $M$. richtersi és az I. prosostomus.

A vizsgálati mintákban talált fajok közül három: $M$. echinogenitus,

I. latiunguis és D.(A.) prorsirostre új a Somogy megyei Tardigrada faunára.

A fenti három fajjal együtt a Somogy megye területéről eddig kimutatott Tardigrada fajok száma: 58 .

A kimutatott 14 faj a Somogy megyei fajok $24 \%$-a, a Dunántúl területéről ismert 114 faj $12 \%$-a és a hazai Tardigrada-fauna (123 faj) $11 \%$-a.

\section{3. táblázat: A Látrányi Puszta Természetvédelmi Terület moha- és zuzmómintáiból} kimutatott Tardigrada fajok jegyzéke

Osztály: Eutardigrada Marcus, 1927

Rend: Parachella Schuster, Nelson, Grigarick et Christenberry, 1980

Család: Macrobiotidae Thulin, 1928

Nem: Macrobiotus Schultze, 1834

1.

2.

3.

Macrobiotus echinogenitus Richters, 1903

.

4. - Macrobiotus hufelandi Schultze, 1833 Macrobiotus richtersi Murray, 1911

Nem: Xerobiotus Bertolani et Biserov, 1996

5. Xerobiotus pseudohufelandi (Iharos, 1966)

Nem: Minibiotus Schuster, Nelson, Grigarick et Christenberry, 1980

Család: Hypsibiidae Pilato, 1969

6.

Nem: Hypsibius Thulin, 1928

7.

8.

9.

10.

11.

12.

13.

14.
Hypsibius pallidus Thulin, 1911

Nem: Isohypsibius Thulin, 1928

Isohypsibius bakonyiensis (Iharos, 1964)

Isohypsibius latiunguis (Iharos, 1964)

Isohypsibius pappi (Iharos, 1966)

Isohypsibius prosostomus Thulin, 1928

Nem: Diphascon Plate, 1889

Alnem: Diphascon Pilato, 1987

Diphascon (Diphascon) bullatum Murray, 1905

Diphascon (Diphascon) pingue (Marcus, 1936)

Alnem: Adropion Pilato, 1987

Diphascon (Adropion) prorsirostre Thulin, 1928

Nem: Ramazzottius Binda et Pilato, 1986

Ramazzottius sp. 


\title{
Köszönetnyilvánítás
}

A szerző őszinte köszönetét fejezi ki Héra Zoltánnak a vizsgálati minták begyüjtéséért.

\section{Irodalom}

VARGHA B. 1997: Környezetszennyező anyagok hatásának ökotoxikológiai és bioindikációs vizsgálata. II. rész Nematoda-teszt, bioindikáció mohalakó Tardigradákkal. Egészségtudomány 41: 152-164.

VArGha B., Iharos Gy. 2001: Medveállatka (Tardigrada) fajok előfordulása Somogy megyében. in: Somogy fauna katalógusa, Natura Somogyiensis $1: 41-48$.

\section{Data to the water-bear (Tardigrada) fauna of Látrányi Puszta Nature Conservation Area}

\author{
BÉLA VARGHA
}

In the course of 2001, 73 moss and lichen samples were collected to survey the waterbear fauna of Látrányi Puszta Nature Conservation Area (Fig. 1). One third of the samples did not contain any water-bears.

Altogether 14 species were recorded (Table 3). Samples from the ground and from the tree trunks seemed to have the highest abundance in species. The samples examined were usually poor in species, the occurrence of one or two species were typical. The highest number of species occurring together was 5. Macrobiotus richtersi and Isohypsibius prosostomus were the most common species. Macrobiotus echinogenitus, Isohypsibius latiunguis and Diphascon (A.) prorsirostre are new in the tardigrade fauna of Somogy County.

The number of water-bear species currently known in Somogy County is 58 .

The 14 species recorded in the surveyed area make up the $24 \%$ of the tardigrade fauna of Somogy County and it is equivalent to the $12 \%$ of the 114 species known in the Transdanubian region and $11 \%$ of the fauna of Hungary (123 species) 